\title{
A META-REFLECTION ON MY EMERGING AS A SCHOLAR OF ACTION RESEARCH
}

\author{
P. H. du Toit \\ Department of Humanities Education \\ University of Pretoria \\ Pretoria, South Africa \\ e-mail: pieter.dutoit@up.ac.za
}

\section{ABSTRACT}

The self-enquiry reported in this article is conducted at a meta-level of meaning making. A metalevel of reflection is typical of a meta-cognitive mind-set; it entails reflecting on my reflection from a scholarly point of view. The theory on whole brain thinking informs the conceptual framework for my research and teaching practice; therefore I have given new meaning to action research as being whole brain action research, reflection as whole brain reflection, and for the purpose of this article specifically, whole brain meta-reflection. My scholarly reflections focus on what is reported in publications. Data sets gathered over the years are not reported per se as it has already been made public. Instead, I reflect at macro level on existing data. What is made public by means of this article is my reflection on my reflections in the past. It is inevitable that the raw data I have drawn from forms the core of my article. Therefore, a great number of references indicate me as author or co-author.

Keywords: action research, auto-ethnography, constructivism, meta-reflection, professional development trajectory, reflexive practitioner, scholarly community of practice, self-enquiry, whole brain thinking

\section{INTRODUCTION}

Claiming that this article reports a scholarly meta-reflection on a professional development trajectory requires considering the seminal work of Biggs (1985) on meta-cognition. In my numerous publications on the construct whole brain thinking as author (Du Toit 2004a; Du Toit 2012) or co-author (De Boer, Du Toit and Bothma 2015; De Boer et al. 2013) I explain my wish to contribute to the current understanding of phenomena pertaining to higher education teaching practice. I therefore, more often than not, construct new meaning and coin new terms that resonate with my holistic approach to investigating the self. As I coined whole brain reflection as a specific notion of looking at self from different perspectives, I have coined whole brain meta-reflection with a view to contributing to our current understanding of what reflection entails. My initial understanding of reflecting on self was in my earlier years of my emerging 
of a scholar of action research. This is documented in an earlier publication (Du Toit 2001b).

Meta-reflection by nature is a self-regulated act. I consider self-regulated professionalism as the driving force for becoming a scholar of higher education in general and academic staff development in particular. McNiff and Whitehead (2006) as scholars of note who advocate having proof of the claims we make made me realise that integrity is a fundamental virtue of scholarship. I would like to acknowledge McNiff as one of my mentors at an early stage of my academic career. Through this mentor-mentee relationship I came to realise that I had and still have the responsibility to interact at a scholarly level with her and with other scholars I consult with a view to constructing my own meaning as suggested by Le Cornu (2005). I have the responsibility to act as role-model in scholarly communities of practice that came about through my interaction with other scholars - mainly colleagues at my place of work, the University of Pretoria (UP).

Working at one of the largest residential universities in South Africa I am offered the ethnographic context for what I am doing as scholar of higher education and academic staff development. The notion of ethnography, as highlighted in the work of O'Leary (2014), Christensen, Johnson and Turner (2014), Lichtman (2014), Wagenaar and Babbie (2004) is accentuated in my work with colleagues in different faculties. I engage colleagues from different fields of specialisation. This includes veterinary science, health sciences, information science and financial sciences.

Constructivism and co-constructivism enrich my epistemological stance that is holistic in nature as I consider myself a holistic and visionary thinker. Justification for this claim is found in a number of publications (Smit and Du Toit 2016; Du Toit 2016; Du Toit 2013).

\section{REFLECTING ON MY REFLECTION}

Reflecting on my reflection is a meta-cognitive act.

An important source of reflection I can reflect on at meta-level is my updated Curriculum Vitae. It is a document rich in raw data. I reflect on some excerpts. In my view drawing from the raw data generated is typical of text analysis. It is text analysis as the text was created by me. The text in itself is written in the form of a reflexive account of proven scholarship. Next I reflect on my initial reflection. By doing so I take a meta-cognitive position.

\section{RESEARCH SCHOLARSHIP}

As with other international scholars of note, I consider my first involvement in writing a scholarly work - the first book of which I am a co-editor - a seminal work. I humbly pride myself on having been invited by the first editor to become part of the project at the time (Malan 
and Du Toit 1991). It was translated into English (Malan, Du Toit and Van Oostrum 1996).

One cannot negate the fact that self-assessment is reflexive in nature. The outcome of the reflection is documented in different ways. In my case the focus of the reflection is on my scholarship. My meta-reflection on this scholarship brings about documenting my thinking about my thinking at the time of writing it down. I claim that my international standing as scholar was initiated by being invited as guest lecturer/scholar to the Iowa State University (1997) and the University of Oklahoma (1998) in the United States of America. These visits were funded by, inter alia, the United States Agency for International Development, MTN, Anglo Gold and the International Office of the University of Pretoria. Further international collaboration included two research projects between 2001-2003 with the Catholic University of Leuven; these projects from which two co-authored technical reports resulted (Beckman, Van Rooyen, Conradie, Joubert and Du Toit 2002; Beckman, Van Rooyen, Conradie, Joubert, Du Toit and Meyer 2002) were funded by the Flemish Government.

Other invitations came from the University of Nottingham in the United Kingdom (UK) in 2016, the University of Tübingen in Germany in 2017, and from the University of Bath Spa in the UK in 2018. At a level of meta-reflection I claim that these visits were instrumental in my overall scholarship development. During those visits I enacted the different types of reflection as suggested by Schön (1995), namely reflecting before action, reflecting in action and reflecting after action. I still reflect on the numerous cycles of my professional development trajectory on a continuous basis. The imperative I have as an advocate of constructivism urges me to make meaning continuously. I therefore would like to add a fourth dimension to Schön's - that of meta-reflection.

I have now become an advocate of meta-reflection as I expect all my postgraduate students using an action research design for their doctoral or master's studies to include meta-reflection as a last chapter. This allows for reflecting on the action research process, which has reflection as essential step of each action research cycle. Evidence of the need for and the success of having postgraduate students reflect at a deep level of understanding on the importance of reflection can be found in the work of Wolvaardt (2013), Fringe (2013) and De Jager (2011). With this article I wish to act as role-model to my students in taking a meta-reflective stance on what we as action researchers ought to do.

As part of my advocacy for innovation and new meaning making I draw on my studies on whole brain learning as it pertains to me and my way of thinking and doing as reported; examples feature in Du Toit (2008b; 2012) and Smit and Du Toit (2016). These include profiling of my thinking styles. My choice of modes of thinking in the first place indicates a preference for having fun, participating in a spontaneous fashion, playful, surprising 
approaches, visual representations, metaphors and overviews, discovering new meaning, freedom to experiment with innovative ideas. As these are aspects of my being a lecturer and scholar I struggle with administrative duties, documenting progress, and a lack of flexibility in others. Secondly, I have a preference for working with others. As my preferences in this regard revolve around participating as a member of a group. I like sharing ideas, hands-on learning, being personally connected with others, emotional involvement, user-friendly experiences and using all the senses. I struggle with too much data and detail, direct training and instruction, and a lack of opportunities to participate. This scholarly make-up made me aware of why action research has become my research paradigm of choice. My approach is one of being open, being innovative, thinking big picture and using visuals - typical of action research. And since I have a preference for working with others, embarking on a number of participatory action research projects with others as a scholarly community of practice was an option that I embraced. In my quest to find a scholarly home in terms of how I would want to execute research, action research was the niche. Moreover, it became inevitable that I would coin the construct "whole brain action research" (Smit and Du Toit 2016).

As I reflected on my thinking preference profile and report in the articles alluded to above, I now reflect on how I have interpreted the use of the profiling in practice at a meta-level. The following questions arise: To what extent do the claims made of reflecting on the profile serve as a point of departure for my whole brain reflection during the execution of my action research? How does the whole brain approach to my reflection inform my meta-reflection? Can I claim whole brain meta-reflection to be my emerging of a deeper level of understanding of what being a reflexive practitioner entails?

I reflect on the numerous international conferences in which I participated. I add my involvement in being a member of the executive committee of the international association of action research, Action Learning, Action Research and Process Management, based in Australia. This led to entrusting me to organise the $6^{\text {th }}$ ALARPM Conference (2003) for the first time in South Africa. I reflect on the outcome of the Conference. This reflection was made public in an article published in the ALAR journal (Du Toit 2004b). These are some opportunities I accepted with a view to establishing myself as a scholar, working in the field of innovative teaching and learning. My research identity is therefore multi-layered as the scholarship of academic staff development and scholarship of action research - both recognised fields of study within higher education - are inextricably linked.

As an independent and now established senior academic I demonstrate my academic citizenship in various ways. I am serving as a member of the ethics committee of the Faculty of Education. I have the responsibility of critical reviewer of applications for ethical clearance. I 
have been invited by the Foundation for Professional Development (FPD) to serve as member of their ethics committee. Furthermore, I am regularly requested to act as a critical reader of research proposals within my own and other departments of the Faculty. I have also chaired numerous research proposal sessions and continue to do so. I act as mentor to young supervisors. Furthermore, being appointed to act as editor of two issues of an international journal on action research, the journal for Action Learning Action Research (ALAR), confirms my recognition as a scholar of action research. So do the opportunities of acting as guest editor of two issues of $S A J H E$.

I was elected a member of the executive committee of a nationally based association on higher education, namely the South African Association for Research and Development in Higher Education, and later as vice-president. As part of this position I acted as chair of the 2007 SAARDHE Conference presented for the first time at the Faculty in 2007, sponsored by the National Research Foundation. I reflect on this conference in SAJHE (Du Toit 2008a). SAARDHE merged with the Higher Education Learning and Teaching Association Southern Africa. I was elected member of the executive; currently acting as convenor of the Special Interest Group (SIG) on Action Research/Reflexive Practice/Self-enquiry.

In reflecting on the past and what I am currently involved in in terms of research projects, I humbly claim that I am now recognised in both domains - nationally and internationally - for my application of action. My humility is based on the fact that what I have reflected on in the past and reflecting on now is based on the willingness of other people to become involved in my professional development; they were willing to create opportunities and to assist at different levels - be it in terms of executing research or being aware of the importance of refining written work. Owing to limited space I cannot list their names.

I am aware of the fact that an autobiographical stance might be regarded by outsiders as being arrogant. This, however, is not the case. By reporting the reflection on my successes, I would like to inculcate the attribute of self-appraisal in my students. This is a form of professionalism and identity formation that I was deprived of as student, even at postgraduate level, and as young up-and-coming scholar. I continuously had to ask: When will I be considered a scholar of note? From experience I learned that I should affirm scholarship identity and agency in my students. Apart from postgraduate students at $\mathrm{PhD}$ and master's level I wanted to see my students become higher education professionals in their own right - scholars of higher education and specifically self-enquiry and related research designs. A number of my PGCHE students have published the action research projects they embarked on during their PGCHE studies or reported the outcome of their action research at national and international conferences. 
Further affirmation of my scholarly work is evident in my being offered a six-month scholarship for postdoctoral studies by the Flemish Government in 2003-2004. At the University of Antwerp introduced action research as a scholarly foundation for academic staff development and professional development of educators in general. This led to research outputs in collaboration with the project leader, Prof. Peter van Petegem (Du Toit and Van Petegem 2005a; Du Toit and Van Petegem 2005b; Van Petegem and Du Toit 2005).

In reflecting on the expectations, the leadership of the Faculty of Education at UP has had in terms of co-publications opposed to single-authored publications, I always felt like being a scholarly puppet. However, true to the nature of my research, which is most often than not collaborative and participatory my publications and conference papers are co-authored. Many of these have as first author students or colleagues taking part in my professional development initiatives. Those who are not involved in (participatory)action research educational professional development of academic staff often do not appreciate this. I consider my involvement in the scholarship formation and lecturer identity of students and colleagues as a developmental process - one that is underpinned by socio-constructivism as epistemology.

Being invited as quest speaker or co-worker on research projects at national and international level adds to one's standing as scholar. Some such invitations include an invitation by the Baptist University of Hong Kong (Du Toit 2001a) and presenting a meta-reflection on the ALARPM Conference I organised for the first time in South Africa - mentioned earlier in this article - by Prof. Ortrun Zuber-Skerritt at the ALARPM Conference in 2015 (Du Toit 2015). Other important invitations from international scholars of note are an invitation by Prof. Jean McNiff to participate in a panel discussion with her and Prof. Jack Whitehead at the AERA Conference (Du Toit 2008); an invitation by the Ministry of Education Mozambique in 2008 and one to become part of a research project on peer reviewing by Dr Mitch Parsell from the University of Macquarie, Sydney, Australia in 2011 where I presented a paper on invitation (Du Toit 2011). It is with humble gratitude that I list some presentations done that in collaboration with other international scholars of note; with McNiff as part of a panel discussion (Du Toit 2008b) and others (Du Toit 2009; 2016; 2015).

My work is underpinned by action research as an exploratory and developmental research design. My current research interest, innovative approaches to teaching has developed from my quest to improve not only my own practice but also that of lecturers in higher, technical and vocational education. Improving practice does not refer to operational actions but distinctly research-driven scholarly interventions, which I prefer to call initiatives given my asset-based approach taken - as is typical of action research underpinned by a constructivist epistemology. My research advocates the necessity of narrowing the gap between traditional research and the 
scholarship of practice by the practitioner-researcher. This is evident in the two sections that follow.

After my initial introduction to the world of scholarship of action research and practice, my NRF-rating as research scholar and promotion to associate professor was rewarding. My constant and passionate working at the University of Pretoria for more than thirty years confirms that my choice of an academic career was the right one.

\section{SCHOLARSHIP OF TEACHING AND LEARNING}

In reflecting on my teaching at a meta-level of meaning making I needed to reflect on my teaching philosophy that has been reported in a number of publications. In summary my teaching philosophy can best be described by means of the object I use for my teaching practice as is documented in the learning material my students receive (Du Toit 2018) and a chapter in a book (Chisanga et al. 2017) and a presentation at an international conference (Du Toit 2017. It serves as an exemplar of metaphorical thinking about my practice. In the same way I expect my students to think metaphorically about what they do in terms of student learning - an aspect I consider important for monitoring one's practice by means of action learning/research.

Consequently I write about the object of my education practice:

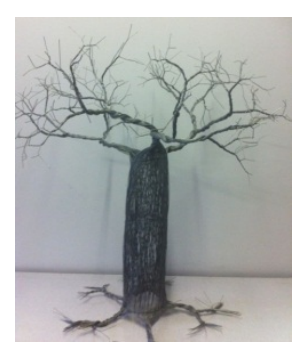

"The legend of the African Baobab is the story of a tree that wished to be the greatest tree in Africa. The wise spirit heard its request, reached down from the sky and pulled the tree from the earth and placed it upside-down. Now it said: I have made you unique. In return, you will grow strong and become an African landmark, known as the tree of life and many will prosper from your growth.

The Africa Baobab is one of the world's hardiest trees, thriving in even the most arid environments. It is also the tree under which some Africans traditionally meet to decide issues of common concern. For many indigenous tribes it is the embodiment of wisdom, reference, teaching, respect, leadership, longevity, health and life. The name Baobab means "the time when man began" and it is therefore no wonder that the San people associated it with the origins of creation."

It is important to me to enact the roles of a lecturer as my students who are my colleagues at UP or other higher education institutions should experience the application of relating principles in my practice. It would, for example, be contradictory should I present a lecture on cooperative learning instead of applying the related principles in my own practice by allowing my students to work in groups.

The cyclical nature of action research permits the practitioner-researcher to explore his or her own teaching practice. My scholarly focus on academic staff development developed over a number of years. This scholarship developed to such an extent that I was entrusted with the 
role of developer and coordinator of the Postgraduate Certificate in Higher Education (PGCHE). This programme is a mainstream professional education qualification for lecturers. It is an action research-driven programme. With a view to promoting this research-driven approach I created an action research model that focuses on the lecturer as an asset. The assetbased approach builds on the strengths and synergy available in organisations as a collective of human resources; researchers and higher education practitioners (academics) and seeks to identify the unique fortes of the lecturer as practitioner-researcher investigating his or her own practice. My effort to provide innovative scholarly direction to practice research and construct practice theory now flows through scholarly communities of practice I am involved in, empowering individual scholars not simply to resort to a simple approach to a research challenge, but a creative one whenever necessary. Because action research is the foundation of the professional development programme (PGCHE) it creates a value adding chain where the knowledge and skills developed in the course are transferred, thus building and enhancing capacity not only within UP but also in other institutions.

Furthermore it has afforded me the opportunity of mentoring my students and colleagues in the research process. Self-evaluation should be based on the intrapersonal view of the self, which includes critical reflection and feedback from students and colleagues.

Feedback from students indicates that they are largely satisfied with the quality of my teaching. This is, as with all aspects of my practice, extremely important as I need to enact all roles in this regard in an exemplary fashion. I offer a few examples of qualitative feedback obtained from students. These are in the form of quotations from students' portfolios or other means, such as emails. One example is email correspondence between me and a student as reported in different publications (Du Toit 2012; De Boer et al. 2013). The student is a qualified medical practitioner. He established a private higher education institution (HEI). It offers management programmes for health sciences practitioners. He has a number of health sciences qualifications, and a PGCHE. I enquired about the latter as he was my student. He responded by indicating that this was the programme he enjoyed most. This was great feedback received from a professional in a leadership position in higher education!

A sample of portfolios was analysed over some time. The sample provides evidence of my contribution made to their learning - I fostered, inter alia, learning of higher order, including constructivist and self-regulated learning, and living theory that includes critical reflection and authentic learning. This indicates that I do not focus on the theory of applicable learning theories for adults only, but that I apply the principles in my practice and that I expect my students to do the same; they are required to give a written account. The following is feedback regarding the quality of my teaching as reported in De Boer et al (2013): 
- "Through my work in this yearlong learning experience I have gained a lifetime of potentially lifelong learning development. If I were asked to account for one specific aspect of this experience that was perhaps most beneficial in the way it has come to underpin my ETDP and transform it, I would have to pinpoint reflective practice. For me reflection ... is the means by which the progressive development of an ETDP gains momentum."

- $\quad$ "This portfolio has been completed with the primary purpose of providing evidence of my personal journey in building meaning within the PGCHE ... to provide a 'big picture' of the development that has taken place over what seems now in retrospect a very short time indeed. ... I have decided to explore other than my preferred ways to construct meaning while building the portfolio and I have written each section with a particular quadrant in mind."

- $\quad$ "I wish to acknowledge the significant role played by my wife ... who encouraged me to enroll for the PGCHE, thereby launching me on a journey of exploration and growth. ... I wanted this action research to develop me as a mentor and agree that action research is a process that helps you ... to develop a deeper understanding about what you are doing as an insider researcher."

- "It was also in the reflection phase that I discovered the true, practical meaning of selfregulated learning - I could see it in my own professional development, and saw it in my students' work, self-motivation and positive attitude."

- $\quad$ "I can conclude that my portfolio gives evidence of my professional development and intrapersonal leadership in the context of lifelong learning. This portfolio displays aspects of meta-learning, reflective learning, action learning, intrinsic motivation, creative thinking, critical thinking, self-assessment and being meta-cognitively aware of my own learning and learning style preference."

My final conclusion refers to claims made about my teaching. My students apply in their respective practices principles of theories they engaged with. And they manage to sustain the construction of new meaning through a collaborative effort. This is evident in the conference papers presented as co-authors.

Other means of promoting creative thinking is to expect students to write poems on what they have to learn. One such poem on action research has been published.

My focus on whole brain learning as a powerful approach to all aspects of teaching and learning compels me to incorporate the applicable principles in practice. One of the means to ensure this is to invite students to have their brain profiles determined to understand themselves better and to use the outcome as point of departure for monitoring ways in which they can become more flexible with a view to accommodating their students with different thinking styles.

Supervision of postgraduate studies is a different form of teaching. The participatory nature of action research promotes reciprocal scholarly learning in scholarly communities of practice. Networking, which mainly revolves around these communities of practice at different levels and in differing contexts, is evident in my involvement in scholarly initiatives as has been 
outlined in the previous section. It reflects the research mentoring and leadership position I fulfil in my research field. I am able to build sustainable relationships with new and established scholars in my field of specialisation at national and international level. My scholarly networks are firmly based on the reciprocal affirmation of what my colleagues from Australia, Europe, the United Kingdom, the United States of America and African countries, as well as South African universities acknowledge as contributing initiatives. Networks have enabled me to benchmark my research and research supervision with national and international scholars. Reports from external examiners, including international renowned academics, such as Prof. Jack Whitehead, who have commended my postgraduate students on stellar work and acknowledged me as an excellent supervisor confirm this. Such positive feedback on my scholarship has resulted in my being invited to act as external examiner of more than twelve master's and PhD studies. I have honed my supervision abilities over the years and have guided to successful completion more than 30 students in the past. Only two were initially in the capacity as co-supervisor under the mentorship of an established academic but soon the scholarly community of the Faculty allowed me to supervise independently.

My quest for innovation in my teaching practice and being an advocate of innovation in general was rewarded in 2014 when I received an award for education innovation from the Department for Education Innovation at the University of Pretoria.

\section{SCHOLARSHIP OF COMMUNITY ENGAGEMENT}

I consider my community engagement to be multi-layered; it involves my involvement in academic staff development initiatives serving other higher education institutions - an external community. At an internal institutional level I was and still am involved in a number of academic staff development initiatives at the University of Pretoria - working with my peers. Serving the University in this way is in the context of the University referred to as academic citizenship. At a different level the University considers work-integrated learning (WIL) as part of community engagement. WIL forms and integral part of the practical experience of students enrolled for the PGCHE.

Firstly, professional development workshops are organised continuously to serve the technical vocational education and training colleges in terms of academic staff development. The Department of Higher Education and Training initiated a focus on the professional development of TVET lecturers. This includes conducting informal workshops. These are organised by the Division of the University responsible for further education and training. Secondly, I was tasked to design a formal qualification for TVET staff development - a Postgraduate Diploma in TVET - as expected by the DHET. This programme is set to be 
implemented in 2020.

Apart from TVET colleges I am involved in the professional development of staff of private higher education institutions. Private higher education institutions such as the Foundation for Professional Development approached me in 2009 to become part of different research initiatives. The institution focuses on the professional development of managers within the cadre of health science practitioners. Research projects include the President's Emergency Plan for Aids Relief that have led to a number of research outputs. Innovative ideas that I advocate are being implemented and have thus enriched the education practice at the Foundation for Professional Development. My involvement with this entity resulted mainly from my expertise in action research. Based on this involvement I was commissioned by the FPD to write a single-authored publication on action research for health science managers (Du Toit 2009). Another private higher education institution that invited me to become involved in academic staff development initiatives and based on my expertise in academic staff development is the Midrand Graduate Institute that thus far has led to one co-authored journal publication (Giloi and Du Toit 2013) and several co-authored conference papers. This institution has invited me to become part of their academic board and to act as assessor of research projects during research showcases and of education innovation awards - recognition of my research identity at another level.

My community enrichment has been extended to other universities nationally and internationally. Workshops I offer are aligned with modules of the PGCHE. Universities involved at national level are the University of Limpopo, the University of the Free State, Cape Peninsula University for Technology and the North-West University.

A community engagement project of note is the initiative that has led to research outputs. It stems from my responding to the call of the Eduardo Mondlane University (EUM) in Maputo, Mozambique to become involved in the professional development of academic staff. This formed part of the mutual agreement signed between the EUM and UP. Apart from my involvement as specialist in action research-driven workshops, my contributions resulted in the successful completion of two $\mathrm{PhD}$ studies by academic staff of the EUM under my supervision (Fringe 2013 and Tembe 2011) and co-authored conference papers.

My involvement with the Department of Family Medicine at my University concerns the educational contribution to a new programme, Bachelor of Clinical Medical Practice. It revolves around whole brain thinking and management, self-regulated learning, etc. The main focus of my involvement is on the development of the staff who teach on the programme (Hugo et al. 2013). I also teach the students about whole brain learning with a view to aligning their learning with the way their lecturers facilitate learning. I have designed a feedback 
questionnaire that I consider learner-centred. It does not only ask the students to give feedback on my facilitating of learning but also on their contribution made in terms of enhancing their own and their peers' learning. Next I list examples of feedback I received from the medical students as reported in De Boer et al. (2013):

- "He allowed everyone to feel free and talk freely and he also provided learning opportunities."

- "The presentation was lively, well-structured and overall applicable to students."

- "Gave an excellent lecture."

- $\quad$ "Made the best of a very 'bad' classroom setting [Group work had to be carried out in an auditorium style venue]."

- "This is the best experience I ever had."

- "I discovered that I try to base a lot of learning on structure opposed to emotions."

- "Think this is a fun way of getting to know yourself and others."

- "A world class presentation."

I am proud to be associated with this Department. One of the reasons is that they received numerous education innovation awards in the past.

I have recently been requested by the Department of Human Resources to offer workshops on mentoring for experienced academic staff that are excellent mentors for newly appointed academic staff. As epistemological stance I promote a constructivist approach to mentoring (Greyling and Du Toit 2008).

Under the leadership of the Head of Department a group of lecturers from the Department of Taxation used the principles of whole brain thinking and group work in their large classes to enrich their practice as most students find the content of taxation quite boring (as I was told by the lecturers involved themselves). They embarked on a project that expected students to suggest an innovative way to educate the public in terms of taxation. Some of the innovative products were board games such as Tax Race and booklets, such as Taxation for Dummies. One publication to mention is that of two colleagues in the Department who implemented the principles of whole brain thinking in their practice with me as third author (Van Oordt, Van Oordt and Du Toit 2014).

In the same manner I work with individual academics as higher education practitioners and scholars. Recently a young practitioner-researcher from the Department of Taxation at UP whom I had mentored received the highest award, namely a Laureate for innovation of practice. I consider these as substantiated examples of my academic citizenship and view my involvement in colleagues' research as a means to promote their scholarly emancipation; I want 
to see, especially newly appointed academics, become independent in terms of executing research projects, and eventually take a leadership position in research teams in their field of specialisation.

Involvement with non-academic entities include other funded research initiatives that I have collaborated in; these are the Basel Regional Centre on waste management training (funded by the Japan International Cooperation Agency (JICA) and education institutions such as Further Education and Training (FET) colleges from the Mpumalanga Province funded by the University of Hiroshima).

\section{CONCLUSION}

The main argument of this article is not the focus on my professional development per se. My professional development is simply a means to illustrate how whole brain action research, professional development and whole brain meta-reflection as a new construct are interlinked. And it serves as exemplar of how higher education practitioners could take their reflection on self and practice to a deeper level of understanding.

As a lead article it serves as an umbrella of all the means of self-enquiry, self-reflection and auto-ethnography by prompting the following question: How can practitioner-researchers elevate what they do in terms of reflecting on practice to a meta-level of meaning making?

\section{REFERENCE LIST}

Beckman, J. L., J. W. van Rooyen, J. J. Conradie, H. J. Joubert and P. H. du Toit. 2002. Technical report Outcomes-based school leadership and management (Eastern Cape, Free State and Limpopo) (Project7). Pretoria: University of Pretoria.

Beckman, J. L., J. W. van Rooyen, J. J. Conradie, H. J. Joubert, P. H. du Toit and G. Meyer. 2002. Technical report 2002: Outcomes-based school leadership and management: An in-service training programme for school principals in the Northern Province (Project 7). Pretoria: University of Pretoria.

Biggs, J. B. 1985. The role of metalearning in study processes. British Journal of Educational Psychology 55: 185-212.

Chisanga, T., G. Ashu, P. Mavume, N. Dhlula-Moruri, M. Khatry-Chhetry, S. Rajkaran, L. Mulenga, N. Sotshangane, N. Gonsalves, P. H. du Toit and D. Pillay. 2017. The vanda, the rose, and the baobab: Inspirational display objects as fertile sites for opening up narratives of teacher researcher professional identities. In Object medleys interpretive possibilities for educational research, ed. D. Pillay, K. Pithouse-Morgan and I. Naicker, 63-80. Rotterdam: Sense Publishers.

Christensen, L. B., R. B. Johnson and L. A. Turner. 2014. Research methods, design, and analysis. Boston (England): Pearson.

De Boer, A-L., P. H. du Toit and T. Bothma. 2015. Activating whole brain ${ }^{\circledR}$ innovation: A means of nourishing multiple intelligence in higher education. TD The Journal for Transdisciplinary Research in Southern Africa 11(2): 55-72.

De Boer, A., P. H. du Toit, D. Scheepers and T. Bothma. 2013. Whole brain ${ }^{\circledR}$ learning in higher 
education: Evidence-based practice. Oxford: Chandos.

De Jager, T. 2011. Beginner-teacher professional development: An action research approach to mentoring. MEd dissertation, University of Pretoria, Pretoria, South Africa.

Du Toit, P. H. 2001a. Learning style flexibility. Multiple Intelligence Conference, 21 June, Baptist University of Hong Kong, Hong Kong.

Du Toit, P. H. 2001b. Professional portfolio building - alternative assessment strategy in teacher education. Educare 30(1 \& 2): 326-346.

Du Toit, P. H. 2004a. Learning styles. In Keys to education psychology, ed. I. Eloff and L. Ebersöhn, 145-163. Cape Town: UCT Press.

Du Toit, P. H. 2004b. Reflecting on the sounds of ALARPM 6 $6^{\text {th }}$ and PAR $10^{\text {th }}$ World Congresss 2003 in Pretoria, South Africa - a persononalised lullaby for four drums. Action Learning Action Research Journal 9(1):3-27.

Du Toit, P. H. 2008a. A personal reflection on the SAARDHE International Conference, 2007. South African Journal of Higher Education 22(6): 1131-1137.

Du Toit, P. H. 2008b. Matching learning style flexibility and action research for academic staff development. AERA Conference, 24-28 March, New York.

Du Toit, P. H. 2009. An action research approach to monitoring one's professional development as manager: Pretoria: Foundation for Professional Development.

Du Toit, P. H. 2011. Departing from home to tandem with a peer - a scholarly approach to intrapersonal leadership PEER Symposium, 22 September, University of Macquarie, Sydney.

Du Toit, P. H. 2012. Using action research as process for sustaining knowledge production: A case study of a higher education qualification for academics. South African Journal of Higher Education 26(6): 1216-1233.

Du Toit, P. H. 2015. From the first ALARPM World Congress in Pretoria to the next ALARA in Pretoria: What happened in between? A meta-reflection by the first South African ALARPM convenor. Celebrating 25 years of ALARA contributions: Developing a learning conference culture. ALARA Conference, 4-7 November, St George Hotel, Pretoria.

Du Toit, P. H. 2016a. Action research as innovative means to self-study: A quest for "thinking out of my box”! Keynote address: SAIDE/OER Africa convening, 17-18 May 2016, Nairobi, Kenya.

Du Toit, P. H. 2016b. An ethnographic account of a snapshot in Prof Graham Duncan's journey of educational professionalism. HTS Teologiese Studies/Theological Studies 72(1): a3275 http://dx.doi.org/101402.v72i1.3275

Du Toit, P. H. 2017. A pair of scissors, 15 A-4 pages and cello tape: A constructivist equation to making meaning of self-regulated and cooperative learning. International Research Symposium and Exhibition. "Not just an object": Making meaning of and from everyday objects in educational research, 3-5 February, Maharani Hotel, Durban.

Du Toit, P. H. 2018. Study manual for Professional Development (PFO) and Mediating Learning (LMD). Pretoria: University of Pretoria.

Du Toit, P. H. and P. van Petegem. 2005a. Cultivating agents of change in education needs change agents in teacher education. 50 ${ }^{\text {th }}$ ICET World Assembly, 12-15 July, University of Pretoria, South Africa.

Du Toit, P. H. and P. van Petegem. 2005b. Learning style flexibility for effective virtual teams. In Teaching and learning in virtual teams, ed. S. P. Ferris and S. Godar, 32-52. Hershey: Information Science Publishing.

Fringe, J. 2013. Critical reflection as essential principle of professional development of academic staff. $\mathrm{PhD}$ thesis, University of Pretoria, Pretoria, South Africa.

Giloi, S. and P. H. du Toit. 2013. Current approaches to the assessment of graphic design in a Higher Education context. International Journal of Arts and Design Education 32(2): 256-268.

Greyling, W. J. and P. H. du Toit. 2008. Pursuing a constructivist approach to mentoring in the higher 
education sector. South African Journal of Higher Education 22(5): 948-956.

Hugo, J. F. M., J. Slabbert, J. M. Louw, T. S. Marcus, M. Bac, P. H. du Toit and J. E. Sandars. 2013. The clinical associate curriculum: The learning theory underpinning the BCMP programme at the University of Pretoria. African Journal of Health Professions Education 4(2): 128-131.

Le Cornu, R. 2005. Peer mentoring: Engaging pre-service teachers in mentoring one another. Mentoring and Tutoring: Partnership in Learning 13(3): 355-366.

Lichtman, M. 2014. Qualitative research for the social sciences. California: SAGE.

Malan, S. P. T. and P. H. du Toit. (Red.). 1991. Suksesvolle onderrig. Riglyne vir dosente, onderwysers en opleiers. [Successful teaching: Guidelines for lecturers, teachers and trainers] Pretoria: Academica.

Malan, S. P. T., P. H. Du Toit, and L. J. van Oostrum, eds. 1996. Successful teaching: Guidelines for lecturers, teachers and trainers. Bureau for Academic Support Services, University of Pretoria.

McNiff, J. and J. Whitehead. 2006. All you need to know about action research. London: SAGE.

O'Leary, Z. 2014. The essential guide to doing your research project. London: SAGE.

Schön, D. A. 1995. The new scholarship requires a new epistemology. Change 27-34.

Smit, T. and P. H. du Toit. 2016. Transforming beginner teacher mentoring interventions for social reform. South African Journal of Education 36(3). http://reference.sabinet.co.za/sa epublication/educat Art.\#1134,12 pages. Doi: 10.15700/saje.v36n3a1134

Tembe, C. 2011. Exploring professional development interventions for improving the teaching practice of primary school teachers. PhD thesis, University of Pretoria, South Africa.

Van Oordt, M. L., T. van Oordt, and P. H. du Toit. 2014. Are two teachers better than one? Meditari Accountancy Research 22(2): 165-185.

Van Petegem, P. and P. H. du Toit. 2005. Is what students see, what they get? Reflections on curriculum development in higher education: A case study. Scientia Experimentalis XLI(1): 125-144.

Wagenaar, T. C. and E. Babbie. 2004. Guided activities for the practice of social research. Australia: Wadsworth.

Wolvaardt, E. 2013. Over the conceptual horizon of Public Health: A living theory of teaching undergraduate medical students. $\mathrm{PhD}$ thesis, University of Pretoria, South Africa. 